\title{
A review on pistachio: Its composition and benefits regarding the prevention or treatment of diseases
}

\author{
Ghaseminasab Parizi M, BSc${ }^{1}$, Ahmadi A, $\mathrm{MSc}^{2}$, Mazloomi SM, $\mathrm{PhD}^{3 *}$ \\ 1- Student of MSc in Nutrition Sciences, Student Research Committee, School of Nutrition and Food Sciences, Shiraz \\ University of Medical Sciences, Shiraz, Iran. 2- Faculty Member, Research Center for Health Sciences, Dept. of Clinical \\ Nutrition, Faculty of Nutrition and Food Sciences, Shiraz University of Medical Sciences, Shiraz, Iran. 3- Associate Prof., \\ Nutrition and Food Sciences Research Center, Dept. of Food Hygiene and Quality Control, School of Nutrition and Food \\ Sciences, Shiraz University of Medical Sciences, Shiraz, Iran
}

\begin{abstract}
Received: January 2016, Accepted: March 2016

Background: The pistachio is a nut produced by about 20 species of shrub. Present-day studies show the health benefits of pistachio in preventing or treating diseases such as diabetes, cardiovascular diseases (CVDs), cancer, multiple sclerosis (MS), and erectile dysfunction.

Materials and Methods: MEDLINE / PubMed, and Google Scholar databases were searched using the keywords of Pistacia vera, Pistacio, chemical composition, anticancer, anti-inflammation, antidiabetic, and antioxydative. Relevant articles published in the last decade were identified and reviewed.

Results: The chemical composition (macronutrients, micronutrients) of pistachio and the main outcomes of treatment with pistachio species were categorized. The possible mechanisms of action of treatment with pistachio species are discussed in this article. Numerous studies have been conducted to investigate the beneficial effects of nuts such as pistachio on health, lipid profile, and diseases.

Conclusions: It is commonly believed that pistachio can be used in the prevention and treatment of diseases such as diabetes, metabolic syndrome, coronary heart disease (CHD), cancer, inflammatory diseases, and MS. This study showed that nuts such as pistachio have many beneficial effects on health, and can be used for controlling different diseases. It seems that the pistachio may have antiinflammatory, anti-diabetic, anti-hyperlipidemia, and anti-proliferation effects and may be recommended for the prevention, improvement, or treatment of diseases such as diabetes, CVD, inflammatory bowel disease (IBS), cancer, and MS.
\end{abstract}

Keywords: Pistachios, Composition, prevention, Treatment, Disease.

\section{Introduction}

Several species of the genus Pistacia are referred to as pistachio. The pistachio is a nut produced by about 20 species of shrub such as the Pistacia vera, Pistacia atlantica, Pistacia terebinthus, Pistacia khinjuk, and Pistacia lentiscus that belong to the cashew (Anacardiaceae) family. Pistachio (Pistacia vera) is cultivated in Iran, the Middle East, United States, and Mediterranean countries (1).

Iran is the largest pistachio producer in the world, yielding about $40 \%$ of the total global production in the year 2009. The U.S. is the second largest after Iran with $27 \%$ of the total global production. Pistachio is produced in the
Central and Eastern areas of Iran. Kerman has $45.5 \%$ and Rafsanjan $20.6 \%$ of the total global pistachio orchards (2). Pistachios comprised $2 \%$ of the total nut consumption in 2005; thus, greater attention should be paid to its properties. Although the pistachio is popular, it has not been investigatedsufficiently as an edible nut. Other nuts have been investigated more than the pistachio (3). Some diseases such as diabetes mellitus type 2, cancer, metabolic syndrome, hyperlipidemia, and

\footnotetext{
Corresponding author: Seyed Mohammad Mazloomi, Nutrition and Food Sciences Research Center, Dept. of Food Hygiene and Quality Control, School of Nutrition and Food Sciences, Shiraz University of Medical Sciences, Shiraz, Iran.

Email: mazloomi@sums.ac.ir
} 
cardiovascular diseases (CVDs) cause many complications leading to death. Nuts, such as pistachio, have dietary fibers, magnesium, and low sodium contents. Fibers produce a feeling of satiety, thus preventing obesity. Magnesium decreases hypertension via its effect on vasodilation. Thus, pistachio may have beneficial effects on weight and lowering hypertension. On the other hand, in many studies pistachio consumption (30-80 g/day) has decreased total cholesterol up to $10.1 \%$ and low-density lipoprotein-cholesterol (LDLC) up to $8.6 \%$ (4-7).

Pistachio is an important source of energy and many nutrients, minerals, antioxidants, and vitamins that are essential for human health (8). Moreover, pistachio kernel has been found to have some medical properties due to its antioxidant and antimicrobial activities (9). The aim of this review study was to report the chemical composition of pistachio and its health benefits in preventing or treating diseases such as diabetes, cardiovascular diseases (CVD), cancer, and multiple sclerosis (MS).

\section{Materials and Methods}

MEDLINE/PubMed, and Google Scholar databases were searched using the keywords of Pistacia vera, chemical composition, anticancer, anti-inflammation, antidiabetic, and antioxydative. Relevant articles published in the last decade were identified and reviewed. In total, 16000 articles were found. After filtering the obtained texts using the aforementioned criteria, 30 articles were selected and the main subjects of each study were selected in this review.

\section{Results}

\section{Chemical composition}

I. Macronutrients

The chemical composition of pistachio depends on cultivar, rootstock, maturity at harvest, and moisture content. The composition of pistachio kernels of various cultivars has been previously studied (10). The constituents of $100 \mathrm{~g}$ of kernel consisted of 55.2-60.5\% oil, $15.0-21.2 \%$ protein, and 14.9$17.7 \%$ carbohydrate (10). Pistachios are one of the richest sources of fiber $(10.3 \mathrm{~g} / 100 \mathrm{~g})$, and $100 \mathrm{~g}$ of pistachio has 600 calories (11). In addition, pistachio contains a high level of energy (12).

II. Micronutrients (minerals)

The composition of minerals in pistachio kernels was: $4.0 \mathrm{mg}$ sodium, 1048-1142 mg potassium, 120-150 mg calcium, 494-514.5 mg phosphorus, 5.8-11.4 mg iron, $1.0-1.4 \mathrm{mg}$ copper, 157.5-165.0 mg magnesium (10), and $9.3 \mathrm{mcg} / 100 \mathrm{~g}$ selenium (12).

III. Vitamins and Antioxidants

Pistachios are a good source of numerous antioxidants, including tocopherols, carotenes, lutein, selenium, flavonoids, and phytoestrogens (5,6beta-carotene,alfacarotene, and cryptoxanthin) which are important sources of vitamin A. Flavonoids, a subclass of phytochemicals, constitute a large group of food constituents, many of which alter metabolic processes and have positive impacts on health. Pistachios are the richest source of phytosterols $(279 \mathrm{mg}$ total phytosterols/100 g; sitosterol $210 \mathrm{mg} / 100 \mathrm{~g}$, as the predominant phytosterol) (13), vitamin B-6 $(1.3 \mathrm{mg} / 100 \mathrm{~g})$, lutein and zeaxanthin (1205 $\mathrm{g} / 100 \mathrm{~g})$, carotenes $(157 \mathrm{~g} / 100 \mathrm{~g})$, tocopherols $(22.5 \mathrm{mg} / 100 \mathrm{~g})$ (14), and isoflavones (anthocyanins, chalcones, dihydrochalcones, dihydroflavonols, flavonols, flavanones, flavones, and isoflavonoids) (3.63 mg/100 mg) (15-18). Some studies have found eriodictyol and anthocyanin in pistachios (19).

The pistachio is also a good source of unsaturated fatty acids (linoleic acid, linolenic acid, and oleic acid) that are essential for the body. Nuts such as pistachios contain a high rate of monounsaturated fatty acids (MUFA) $(>55 \%)(20)$.

The effect of micronuteirents present in pistachio on health

Pistachios are rich in phosphorus which helps to break down meat and other proteins into amino acids. Phosphorus is necessary for 
hormone production and helps the body use B vitamins (12).

Phosphorus deficiency can cause glucose intolerance and abnormally low serum phosphate level (hypophosphatemia), resulting in loss of appetite, anemia, muscle weakness, bone pain, rickets (in children), osteomalacia (in adults), increased susceptibility to infection (21), numbness and tingling sensation in the extremities, and difficulty walking (21). Calcium has an important function in the human body as a structural element, and cofactor for enzymes and proteins, and in cell signaling, mediation of the constriction and relaxation of blood vessels, nerve impulse transmission, muscle contraction, and the secretion of hormones like insulin (22). The maximum calcium levels in the examined pistachio cultivars were about 400-1350 $\mathrm{mg} / \mathrm{kg}$. Pistachio nuts are rich and absorbable sources of calcium (23). Pistachio is rich in non-heme iron (24). Iron is essential to development and health. Iron is a key component of proteins that carry oxygen and has an important role in cellular metabolism. It is essential for cell growth and differentiation. Inadequate dietary iron intake results in inflammatory anemia.

Furthermore, pistachios are rich in $\mathrm{Mg}$ which helps to prevent osteoporosis, and nervous system and immune system diseases (24). Mg is involved in more than 300 essential metabolic reactions and plays an essential role in a wide range of important biologic reactions. The clinical symptoms of its deficiency are hypocalcemia, neuromuscular hyperexcitability, hypokalemia, cardiac dysrhythmias, and acute myocardial infarction (AMI). Pistachios are also rich in K (24). A low serum $\mathrm{K}$ level can be life threatening because of potential negative changes in cardiac rate, rhythm, and conduction, as well as numerous structural and functional alterations in various organs, especially skeletal muscles. The high rate of tocopherol in pistachio prevents heart disease, LDLoxidation, diabetes, and cancer and promotes the immune system.

Table 1: The main outcomes of pistachio intake summarized in order of each study and its properties

\begin{tabular}{|c|c|c|c|c|}
\hline $\begin{array}{c}\text { Author/s } \\
\text { (year) }\end{array}$ & Objectives & $\begin{array}{l}\text { Type of study and } \\
\text { sample size }\end{array}$ & $\begin{array}{c}\text { Pistachio species } \\
\text { dose/duration }\end{array}$ & Main outcomes \\
\hline $\begin{array}{l}\text { Hernández- } \\
\text { Alonso et al. } \\
{ }^{82} /(2015)\end{array}$ & Anti-hyperlipidemia & $\begin{array}{l}\text { RCCT, } 54 \text { subjects with } \\
\text { prediabetes, } 2 \text { groups }\end{array}$ & $\begin{array}{c}\text { Pistachio- } \\
\text { supplemented diet ( } 57 \\
\text { g/day), controlled diet, } \\
4 \text { months each, } \\
\text { separated by a } 2 \text {-week } \\
\text { wash-out }\end{array}$ & $\begin{array}{l}\downarrow \text { (sLDL-P), } \downarrow \text { non-HDL-P i.e. } \\
\text { VLDL-P plus LDL-P), The } \\
\text { percentage of sHDL-P increased } \\
\text { by } 2.23 \% \text { compared with a } \\
\text { reduction of } 0.08 \% \text { after the CD, } \\
\text { the overall size of HDL-P } \\
\quad \downarrow \text { in the PD }\end{array}$ \\
\hline $\begin{array}{c}\text { Gulati et } \\
\text { al. }^{86} /(2014)\end{array}$ & $\begin{array}{l}\text { Body composition, metabolic, } \\
\text { inflammatory, and oxidative } \\
\text { stress parameters }\end{array}$ & $\begin{array}{l}\text { RCT, } 60 \text { individuals } \\
\text { with metabolic } \\
\text { syndrome }\end{array}$ & $\begin{array}{l}\text { Unsalted pistachios } \\
(20 \% \text { energy) for } 24 \\
\text { weeks }\end{array}$ & $\begin{array}{c}\downarrow: \text { WC, FBG, total } \\
\text { cholesterol, LDL, hs-CRP, TNF- } \\
\text { a, FFAs, TBARS, and } \\
\text { adiponectin levels }\end{array}$ \\
\hline $\begin{array}{l}\text { Sauder et al. } \\
65 /(2014)\end{array}$ & - & $\begin{array}{l}\text { RCCT, } 30 \text { adults ( } 40 \text { to } \\
74 \text { years of age) with } \\
\text { type } 2 \text { diabetes }\end{array}$ & $\begin{array}{l}\mathrm{P}, 20 \% \text { of total energy } \\
\text { for } 4 \text { weeks }\end{array}$ & $\begin{array}{l}\downarrow \text { Systolic BP, } \downarrow \text { total peripheral } \\
\text { resistance, } \uparrow \text { cardiac output, } \\
\text { improved some measures of } \\
\text { heart rate variability }\end{array}$ \\
\hline $\begin{array}{l}\text { Nieman et } \\
\text { al. }{ }^{87} /(2014)\end{array}$ & $\begin{array}{l}\text { Inflammation, oxidative stress, } \\
\text { immune dysfunction, metabolite } \\
\text { shifts }\end{array}$ & $\begin{array}{l}\text { RCT, } 19 \text { adults in two } \\
\text { 75-km cycling time } \\
\text { trials }\end{array}$ & $\begin{array}{l}\text { Pistachio nut, } 3 \\
\text { oz./day, } 2 \text { weeks }\end{array}$ & $\begin{array}{l}\text { reduced } 75-\mathrm{km} \text { cycling time trial } \\
\text { performance and increased post- } \\
\text { exercise plasma levels of } \\
\text { raffinose, sucrose, and } \\
\text { metabolites related to leukotoxic } \\
\text { effects and oxidative stress }\end{array}$ \\
\hline $\begin{array}{l}\text { Gentile et al. } \\
88 /(2014)\end{array}$ & $\begin{array}{l}\text { Effects of HPE and its } \\
\text { (PPF) in a cell model }\end{array}$ & $\mathrm{RCT}$ & Pistacia vera $\mathrm{L}$. & $\begin{array}{l}\text { HPE } \downarrow d \text { prostaglandin (PG) E2 } \\
\text { production, IL- } 6 \text { and IL- } 8 \\
\text { release, and cyclooxygenase } \\
\text { (COX)- } 2 \text { expression, inhibited } \\
\text { the increase in paracellular by } \\
\text { reduced NF-jB activation }\end{array}$ \\
\hline
\end{tabular}




\begin{tabular}{|c|c|c|c|c|}
\hline $\begin{array}{l}\text { Shahraki et } \\
\text { al. }{ }^{2} /(2014)\end{array}$ & $\begin{array}{l}\text { Evaluation of the } \\
\text { cytoprotection, ROS formation, } \\
\text { lipid peroxidation, protein } \\
\text { carbonylation, mitochondrial } \\
\text { and lysosomal membrane } \\
\text { damages in cell toxicity models }\end{array}$ & $\begin{array}{l}\text { Experimental study, } \\
\text { Male Sprague-Dawley } \\
\text { rats }(280-300 \mathrm{~g})\end{array}$ & $\begin{array}{c}\text { Extracts and bioactive } \\
\text { compounds in Pistacia } \\
\text { vera, } 100 \mu \mathrm{l}\end{array}$ & $\begin{array}{c}\text { Cytoprotective activity of } \\
\text { Pistacia vera extracts against } \\
\text { oxidative and carbonyl stress in } \\
\text { type } 2 \text { diabetes }\end{array}$ \\
\hline $\begin{array}{l}\text { Bagheri et } \\
\text { al. }^{89} /(2014)\end{array}$ & - & $\begin{array}{l}\text { Case-control, } 113 \\
\text { patients with MS and } \\
113 \text { healthy women }\end{array}$ & $\begin{array}{l}\text { Fresh nuts (walnut, } \\
\text { hazelnut, almond, and } \\
\text { pistachio) in the diet, } \\
\text { more than five times a } \\
\text { week }\end{array}$ & had a protective role for MS \\
\hline $\begin{array}{l}\text { Kasliwal et } \\
\text { al. }{ }^{64} /(2014)\end{array}$ & Effect on vascular health & $\begin{array}{l}\text { RCT, } 60 \text { adults with } \\
\text { mild dyslipidemia }\end{array}$ & $\begin{array}{l}40 \mathrm{~g} \text { or } 1.5 \mathrm{oz} \text { shelled } \\
\text { pistachios every day } \\
\text { for three months }\end{array}$ & $\begin{array}{c}\uparrow \text { HDL-C and a } \downarrow \text { LDL-C, total } \\
\text { cholesterol to HDL-C ratio and } \\
\text { FBS, improvements in vascular } \\
\text { stiffness }\end{array}$ \\
\hline $\begin{array}{l}\text { Holligan et } \\
\text { al. }{ }^{2} /(2014)\end{array}$ & $\begin{array}{l}\text { Effects on the cardiometabolic } \\
\text { profile }\end{array}$ & $\begin{array}{l}\text { RCT, } 28 \text { individuals } \\
\text { with elevated LDL } \\
\text { levels }\end{array}$ & $\begin{array}{l}\text { Control diet }(25 \% \\
\text { TF); (1PD; } 30 \% \mathrm{TF}) \\
\text { (2PD; } 34 \% \mathrm{TF})\end{array}$ & $\begin{array}{l}\downarrow \text { sdLDL levels following the } \\
\text { 2PD, ATP-binding cassette } \\
\text { transporter A1-mediated serum } \\
\text { cholesterol efflux capacity }\end{array}$ \\
\hline
\end{tabular}

Five study meals

Three meals had $50 \mathrm{~g}$ available CHO:

Effect on postprandial glucose Kendall et and insulin levels, gut hormones al. ${ }^{63} /(\mathbf{2 0 1 4})$ related to satiety and endothelial function
RCT, 20 subjects with metabolic syndrome
(WB50g),

$(\mathrm{WB}+\mathrm{B}+\mathrm{Ch})$ and $(\mathrm{WB}+\mathrm{P})$

Two meals had $12 \mathrm{~g}$ white bread and pistachios, 5-10 weeks

Alonso et al.
${ }_{6} /(\mathbf{2 0 1 4})$$\quad \begin{gathered}\text { Reducing the prediabetes stage } \\ \text { and improving its metabolic risk } \\ \text { profile }\end{gathered}$

\begin{tabular}{cc}
$\begin{array}{c}\text { Askari et } \\
\text { al. }^{59} /(\mathbf{2 0 1 3})\end{array}$ & Lipid profile \\
\hline $\begin{array}{c}\text { Fischer et } \\
\text { al. }^{62} /(\mathbf{2 0 1 3})\end{array}$ & Metabolic diseases and cancer
\end{tabular}

\begin{tabular}{cc}
\hline $\begin{array}{c}\text { Farzanegi et } \\
\text { al. }{ }^{90} /(\mathbf{2 0 1 3})\end{array}$ & $\begin{array}{c}\text { Glutathione peroxidase levels } \\
\text { and total oxidative capacity of } \\
\text { liver and plasma lipid profile }\end{array}$ \\
\hline
\end{tabular}

\begin{tabular}{|c|c|}
\hline $\begin{array}{l}\text { London et } \\
\text { al. }{ }^{50} /(2013)\end{array}$ & Blood lipid profile \\
\hline $\begin{array}{c}\text { Davarynejad } \\
\text { et al. }{ }^{23} \\
(2012)\end{array}$ & $\begin{array}{l}\text { Concentration of nutrient } \\
\text { elements }\end{array}$ \\
\hline
\end{tabular}

\section{RCT, 54 subjects, two Pistachios, 57 g/day, diets} years hazelnuts
Overview of the current state of research relating to the health potential of nuts

Experimental study, 28

female rats (weight: $155.8 \pm 2.7 \mathrm{~g}), 4$ groups

Review
Pistachio reduced postprandial glycemia, increased glucagonlike-peptide levels and may have insulin-sparing properties

$\downarrow$ FBS, insulin, and HOMA of insulin resistance, $\downarrow$ fibrinogen, oxidized LDL, and platelet factor $4, \uparrow$ glucagon-like peptide-1

A cross-sectional survey Walnuts, almonds, Link between high nut of 9660 adults aged $+19 \quad$ pistachios, and consumption and lower total cholesterol

Nut

Pistacia atlantica extract, 8 weeks

Pistachios intake
Associated with a variety of health promoting effects

did not have significant effect on antioxidant and lipid profile levels $\downarrow$ TC and LDL-C fractions, a beneficial change in TC/HDL-C and LDL-C/HDL-C of rats Protein content for examined cultivars varied between 13.75 and $28.13 \mathrm{~g} / 100 \mathrm{~g}$, and N: 2.2$4.5 \mathrm{~g} / 100 \mathrm{~g}, \mathrm{P}: 350-550 \mathrm{mg} / 100$ g, K: $500-1100 \mathrm{mg} / 100 \mathrm{~g}$, and Ca: $40-135 \mathrm{mg} / 100 \mathrm{~g}$

Most important commercially cultivated pistachio in Iran, Pistacia atlantica, Pistacia vera

42 g pistachios (RSG), a $70 \mathrm{~g}$ pistachio (HSG), and no pistachios (DCG) for 12 weeks
No significant changes in body weight or BMI and waist-to-hip ratio in any groups, serum TG sign lower in the RSG group, no significant change in HSG or DCG groups
RCT, 90 subjects with metabolic syndrome

\footnotetext{
Mandalari et al.

${ }_{91} /(2012)$

Quantified the release of polyphenols, xanthophylls (lutein), and tocopherols from pistachios during simulated human digestion
}

Raw, roasted and salted pistachios, and muffins made with raw pistachios
Beneficial relation between pistachio consumption and health-related outcomes 


\begin{tabular}{|c|c|c|c|c|}
\hline $\begin{array}{l}\text { Baer et al. } \\
\quad(2012)\end{array}$ & Metabolisable energy contained & RCT, 16 volunteers & $\begin{array}{l}\text { Pistachio, } 0,42 \text { and } 84 \\
\text { g/day for } 3 \text { weeks }\end{array}$ & $\begin{array}{c}\text { lowered LDL-C, no significant } \\
\text { change in total plasma } \\
\text { cholesterol, HDL, or TAG }\end{array}$ \\
\hline $\begin{array}{l}\text { Kennedy et } \\
\text { al. }{ }^{41} /(2011)\end{array}$ & $\begin{array}{l}\text { Determine fullness and } \\
\text { satisfaction }\end{array}$ & $\begin{array}{c}\mathrm{RCT}, 118 \text { faculty and } \\
\text { staff at a mid-western } \\
\text { university }\end{array}$ & $\begin{array}{c}\text { pistachios on their } \\
\text { desks for an 8-hour } \\
\text { period on two separate } \\
\text { days } \\
\end{array}$ & $\begin{array}{l}\text { Subjects in condition one } \\
\text { consumed significantly fewer } \\
\text { calories }\end{array}$ \\
\hline $\begin{array}{l}\text { Sari et al. } \\
4 /(2010)\end{array}$ & $\begin{array}{c}\text { Antidiabetic, } \\
\text { antihyperlipidemia, } \\
\text { antioxidative stress, and anti- } \\
\text { inflammatory effects }\end{array}$ & $\begin{array}{c}\text { RCT, } 32 \text { healthy young } \\
\text { men (age range: } 21-24 \\
\text { years) }\end{array}$ & $\begin{array}{l}\text { Pistacia vera L., } 20 \% \\
\text { of daily caloric intake } \\
\text { for } 4 \text { weeks }\end{array}$ & $\begin{array}{c}\downarrow \text { Glucose, LDL, total } \\
\text { cholesterol, and TG, decreased } \\
\text { serum interleukin-6, TOS, lipid } \\
\text { hydroperoxide, MDA, and } \\
\text { increased superoxide dismutase, } \\
\text { no significant change in C- } \\
\text { reactive protein and TNF-a }\end{array}$ \\
\hline $\begin{array}{l}\text { Kay et al. } \\
40 /(2010)\end{array}$ & $\begin{array}{l}\text { Serum antioxidants and } \\
\text { biomarkers of oxidative status }\end{array}$ & $\begin{array}{l}\text { RCCT, } 28 \text { adults with } \\
\text { hypercholesterolemia }\end{array}$ & $\begin{array}{c}1 \mathrm{PD} ; 10 \% ; 2 \mathrm{PD} ; \\
20 \% \text { energy from } \\
\text { pistachios for } 4 \text { week }\end{array}$ & $\begin{array}{c}\text { Increases in serum lutein and g- } \\
\text { tocopherol } \downarrow \text { serum oxidized- } \\
\text { LDL }\end{array}$ \\
\hline $\begin{array}{l}\text { Li et al. } \\
{ }^{\prime} /(2010)\end{array}$ & $\begin{array}{l}\text { Effects on body weight and } \\
\text { lipid levels in obese participants }\end{array}$ & $\begin{array}{l}\text { RCT, } 59 \text { Participants to } \\
\text { consume } 1 \text { of } 2 \\
\text { isocaloric weight } \\
\text { reduction diets }\end{array}$ & $\begin{array}{c}53 \mathrm{~g}(240 \mathrm{cal}) \text { of } \\
\text { salted pistachios }(\mathrm{n}= \\
31) \text { or } 56 \mathrm{~g} \text { of salted } \\
\text { pretzels }(220 \mathrm{cal} ; \mathrm{n}= \\
28) \text { for } 12 \text { weeks }\end{array}$ & $\begin{array}{l}\text { Both groups lost weight, } \\
\downarrow \text { triglycerides in the pistachio } \\
\text { group }\end{array}$ \\
\hline $\begin{array}{l}\text { Alturfan et } \\
\text { al. }^{27} /(2008)\end{array}$ & $\begin{array}{l}\text { Effects on blood lipids, } \\
\text { antioxidant activity, oxidative } \\
\text { stress, and sialic acid levels }\end{array}$ & $\begin{array}{l}\text { Experimental study, } \\
\text { high-fat-fed rats }\end{array}$ & Pistachio, for 8 weeks & $\begin{array}{c}\text { ^TC,TG, sialic acid and } \\
\text { thiobarbituric acid-reactive } \\
\text { substances } \\
\end{array}$ \\
\hline $\begin{array}{l}\text { Gebauer et } \\
\text { al. }{ }^{25} /(2008)\end{array}$ & $\begin{array}{l}\text { CVD risk factors, dose-response } \\
\text { relations, and lipid-lowering } \\
\text { mechanisms }\end{array}$ & $\begin{array}{c}\text { RCCT, } 28 \text { individuals } \\
\text { with LDL-C } 2.86 \\
\text { mmol/l consumed } 3 \\
\text { isoenergetic diets for } 4 \\
\text { weeks each }\end{array}$ & $\begin{array}{c}1 \mathrm{PD} ; 10 \% \text { of energy, } \\
2 \mathrm{PD} ; 20 \% \text { of energy } \\
\text { from pistachios; } 34 \% \\
\text { total fat; } 8 \% \text { SFAs, } \\
15 \% \text { MUFAs, and } 8 \% \\
\text { PUFAs } \\
\end{array}$ & $\begin{array}{l}\downarrow \text { Total cholesterol, LDL, non- } \\
\text { HDL-C, apo B, apo B/apo A-I, } \\
\text { and plasma SCD activity } \\
\text { The } 1 \text { PD and } 2 \text { PD, } \downarrow \text { total } \\
\text { cholesterol/HDL-C (1\% and } \\
8 \%), \text { LDL-C/HDL-C }\end{array}$ \\
\hline $\begin{array}{l}\text { Gebauer et } \\
\text { al. }{ }^{25} /(2008)\end{array}$ & $\begin{array}{c}\text { Effects on lipids and } \\
\text { lipoproteins, apo L, and plasma } \\
\text { fatty acids, cholesteryl ester } \\
\text { transfer protein and SCD } \\
\end{array}$ & $\begin{array}{c}\text { RCCT, } 28 \\
\text { hyperlipidemia }\end{array}$ & $\begin{array}{l}2 \text { doses of pistachios } \\
\text { (1 PD; } 10 \%, 2 \text { PD; } \\
20 \% \text { of energy), for } 4 \\
\text { weeks each }\end{array}$ & $\begin{array}{c}\text { The } 1 \text { PD and } 2 \text { PD, elicited a } \\
\text { dose-dependent lowering of } \\
\text { TC/HDL, LDL/HDL, and non- } \\
\text { HDL/HDL }\end{array}$ \\
\hline $\begin{array}{l}\text { Aksoy et al. } \\
92 /(2007)\end{array}$ & $\begin{array}{l}\text { Effects on lipid oxidation and } \\
\text { serum antioxidant levels }\end{array}$ & $\begin{array}{l}\text { Experimental study, } \\
\text { Rats, three groups }(\mathrm{n}= \\
12 \text { for each) }\end{array}$ & $\begin{array}{c}\text { Pistachios } 10 \%, 20 \%, \\
\text { and } 40 \% \text { of daily } \\
\text { caloric intake for } 10 \\
\text { weeks } \\
\end{array}$ & $\begin{array}{l}\text { Consumption of pistachio as } \\
20 \% \text { of daily caloric intake leads } \\
\text { to } \downarrow \text { HDL and TC/HDL ratio and } \\
\text { inhibits LDL-C oxidation }\end{array}$ \\
\hline $\begin{array}{l}\text { Kocyigit et } \\
\text { al }^{29} /(2006)\end{array}$ & $\begin{array}{l}\text { Antihyperlipidemia, } \\
\text { antioxidative stress, and anti- } \\
\text { inflammatory effects }\end{array}$ & $\begin{array}{c}\text { RCT, } 24 \text { healthy men } \\
\text { and } 20 \text { healthy women } \\
\text { (mean age of } 33.4 \\
\text { years) }\end{array}$ & $\begin{array}{l}\text { Pistachio nuts for } 20 \% \\
\text { of their daily caloric } \\
\text { intake for } 3 \text { weeks }\end{array}$ & $\begin{array}{l}\downarrow \text { Oxidative stress, and improved } \\
\text { total cholesterol and HDL levels } \\
\text { HDL and AOP levels, and } \\
\text { AOP/MDA ratios were } \\
\text { significantly increased, } \\
\text { triglyceride and LDL }\end{array}$ \\
\hline
\end{tabular}

MS: Multiple sclerosis; TNF-a: Tumor necrosis factor-a; TOS: Total oxidant status; MDA: Malondialdehyde; RCT: Randomized controlled trial; RCCT: Randomized cross-over clinical trial; sLDL-p: Small low-density lipoprotein particles; non-HDL-P: Non-high-density lipoprotein particles; CD: Control diet; PD: Pistachio diet; $\uparrow:$ Increased significantly; $\downarrow$ : Decreased significantly; IIEF: International Index of Erectile Function; PCDU: Penile color Doppler ultrasound; PUFAs: Polyunsaturated fatty acids; PPF: Polymeric proanthocyanidin fraction; HPE: Hydrophilic extract from Sicilian pistachio nut; DB-RCCT: Double-blind, randomized, placebo-controlled, crossover trial; FBG: Fasting blood glucose; CRP: C-reactive protein; sBP: Systolic blood pressure; apo L: Apo lipoprotein; SCD: Indexes of plasma stearoyl-CoA desaturase activity; sdLDL: Small and dense LDL; 1PD: One serving of pistachios per day; 2PD: two servings of pistachios per day; WB: White bread; $(\mathrm{WB}+\mathrm{B}+\mathrm{Ch})$ : White bread, butter, and cheese; $\mathrm{WB}+\mathrm{P}$ : white bread and pistachios

\section{Pistachio and Lipids profiles}

Epidemiologic and clinical studies have demonstrated that nut consumption decreases the risk of different diseases. Many studies (Table 1) have shown the beneficial effects of pistachios (15-20\% of energy) on lipids and lipoproteins in the body (25). Some studies have shown that the regular intake of nuts has good effects on lipid profile and decreases the serum LDL-C, but it does not significantly affect triglycerides or HDL-C (26). The decrease in serum LDL-C may be caused by phytosterols in nuts. Phytosterols decrease cholesterol via binding to it in the body, and pistachio is rich in phytosterols $(214 \mathrm{mg} / 100$ g) (27). The effects of nut consumption on 
blood lipids and other biomarkers have been investigated in more than 40 intervention trials. Interventional studies on pistachios have shown its beneficial effects on lipids (28-30). Studies have shown that pistachios can improve blood lipid profiles in subjects with moderate hypercholesterolemia, and in turn, reduce the risk of CVDs (31). When pistachios were given to (32) healthy young men for 4 weeks, significant decreases in blood glucose, total cholesterol, and serum interleukin-6 were observed, with improved endothelium vasodilation and total antioxidant status (33). The consumption of pistachios has been shown to significantly decrease oxidative stress, and improve total cholesterol and its LDL levels in healthy volunteers (34). Li et al. showed that pistachio consumption decreased plasma triacylglycerols and body weight when compared with a carbohydrate snack in obese subjects (35), and also revealed that among 50 foods, pistachio contains the highest amount of antioxidants (36). Studies have shown that its kernel protects hepatocytes against oxidative stress. The consumption of pistachios for a long duration of time has a useful nutritional effect during the prediabetic states. Studies have shown that pistachios have a glucoselowering and insulin-lowering effect, thus, promoting a healthier metabolic profile (37, 38).

Consumption of pistachio nuts, as a snack, has beneficial effects on glycemic control, blood pressure, obesity, and inflammation markers in diabetic patients (28). The beneficial effect of pistachios on lipid profiles may be due to essential fatty acids (EFAs) in its composition.

\section{Pistachio and weight gain}

Nut consumption may lead to weight gain in the population at large, especially in obese subjects and those with high lipids profiles due to its high fat content. Li et al. reported that the daily consumption of a defined quantity of pistachio nuts, when compared to an isocaloric refined carbohydrate snack, did not interfere with weight loss and improved triglyceride levels in a weight loss trial (39). Some results (33) indicate that the daily consumption of either a high dose or recommended dose of pistachio nuts for 12 weeks, compared with a control group, resulted in no changes in the body mass index (BMI) or waist-to-hip ratio. These results were consistent with those in other populations (30-34). Nuts may be helpful in the regulation of body weight through inhibiting the appetite and fat absorption (4043).

Other studies have shown that the lipid in nuts (pistachios) is more poorly absorbed than other food sources. Baer et al. reported that the measured energy density of pistachios was $22.6 \mathrm{~kJ} / \mathrm{g}$, which is $5 \%$ less than the currently accepted energy value of $23.7 \mathrm{~kJ} / \mathrm{g}$ calculated using the Atwater general factors (43).

The decrease in weight gain is because of the fiber content, slower digestion, and protein in pistachio, which increase satiety (42). Although pistachio has a high fat content, it is the source of unsaturated fatty acids. The unsaturated fatty acids and high protein content of pistachios can cause an increase in resting energy expenditure and diet-induced thermogenesis (43). However, several other bioactive compounds are present in pistachio which can decrease weight gain (44).

\section{Pistachio effect on diseases}

Pistachio and metabolic syndrome, diabetes and coronary heart disease

Metabolic syndrome consists of metabolic abnormalities, including abdominal obesity, increased blood pressure, and blood glucose and lipid abnormalities often known as prediabetes. Obesity and metabolic syndrome are common in developing countries, (45) and are associated with diabetes and increased CVD mortality (46). Aminotransferase levels in obesity are associated with insulin resistance and metabolic syndrome and the aminotransferase level was significantly lowered with the consumption of pistachios $(47,48)$. Epidemiological evidence has shown that continuous ingestion of nuts is beneficial in the reduction of risk factors of coronary heart disease (CHD) (49). Increased consumption of pistachios has been shown to improve the blood glucose level, endothelial 
function, and some indices of inflammation and oxidative status in healthy young men (50). Data suggest that pistachios have a glucose-lowering and insulin-lowering effect, promote a healthier metabolic profile, and reverse certain metabolic deleterious consequences of prediabetes (51). Some of these beneficial effects may be related to the antioxidants naturally present in pistachio, since pistachio consumption has been shown to reduce oxidative stress markers in healthy subjects (29). Pistachios have a low glycemic index. The study conducted by Josse (52) indicated that, when consumed together with high carbohydrate foods, pistachios decreased the absorption of carbohydrate, and postprandial blood glucose (43). Some clinical trials with statins suggest that this will result in a reduction of $9-12 \%$ in the risk of CHD (53).

Prospective studies show that total cholesterol/HDL-C and LDL-C/HDL-C ratios are more powerful predictors of CVD risk than LDL-C alone (54-56). Some studies, using doses of $15-20 \%$ of total energy of pistachios, found no significant changes in LDL-C, VLDL-C, triacylglycerols, apo A-I, or apo B (57-59). Perhaps, they relied on participants to consume pistachios (and replace other foods) under free-living conditions and assessed their intake by diet records.

It can be concluded that regular consumption of nuts (pistachio, and etc.), particularly 4 times a week, may result in lower dyslipidemia occurrences and may have cardio-protective effects (60).

The provision of $20 \%$ of total calories by consumption of pistachios (61) or $40 \%$ of the required fat by consumption of walnuts and almonds (62) showed no effect on blood pressure in healthy individuals $(61,63)$ and subjects with hypercholesterolemia (16). In a one-year trial, the participants; blood pressure was lowered significantly (64). Compared with white bread, pistachio consumption reduced postprandial glycemia, increased glucagon-like peptide levels, and might have had insulinsparing properties (65). Frequent consumption of pistachios not only improves glycemic and lipid parameters, but also results in improvements in vascular stiffness and endothelial function (66).

A moderate-fat diet containing pistachios modestly improves some cardiovascular risk factors in adults with well-controlled type 2 diabetes (67). Protein, dietary fiber, potassium, magnesium, vitamin $\mathrm{K}$, g-tocopherol, and a number of phytochemicals are beneficial for the heart, and are abundant in pistachios (68). Replacement of low-fat snacks with pistachios about $20 \%$ of the daily energy intake modifies systemic hemodynamics, increases heart rate variability, and reduces ambulatory blood pressure in adults with well-controlled type 2 diabetes (69). Nutrients in pistachios (monounsaturated fatty acids, antioxidants such as vitamin E, lutein, b-carotene, and proanthocyanidins) have antioxidant properties $(29,40)$ and may protect the liver against oxidative stress (43).

With pistachio-enriched diets there were higher plasma lutein, a-carotene, and bcarotene concentrations than the baseline diet and higher lutein and g-tocopherol in $2 \mathrm{PD}$ only. Pistachio-enriched treatment diets significantly decreased serum oxidized-LDL in participants; this was related to the control of diet. Oxidized-LDL is recognized as a contributing factor in the initiation and progression of CVD $(70,71)$. The decrease in oxidized-LDL was related to a significant increase in serum concentrations of antioxidants; thus, pistachios have a beneficial effect on concentrations of serum antioxidants (72).

Frequent pistachio consumption is a useful nutritional strategy for the prediabetic state. Data suggest that pistachios have a glucoselowering and insulin-lowering effect, create a healthier metabolic profile, and reverse certain metabolic deleterious consequences of prediabetes (73).

The beneficial effect of pistachio on CHD, metabolic syndrome, and diabetes may be due to the EFAs and antioxidants in its composition. 
Pistachio and Multiple sclerosis (MS)

MS is a disease of the central nervous system (CNS). Lesions make it difficult to send messages from the brain to the body. These lesions are formed when the immune system attacks the protective covering of the nerves called the myelin. Oligodendrocyte damage and subsequent axonal demyelination is a hallmark of this disease. The cause of MS is unknown. Studies show that nutrition is effective in controlling the progression of the disease (74). Polyunsaturated fatty acids (PUFAs) exert immunosuppressive actions through their incorporation in immune cells and may affect CNS cell function. Antioxidants and PUFAs have the potential to decrease disease symptoms through specific pathomechanisms. EFAs have been linked to improvement of immune responses $(75,76)$. Pistachios are rich in EFAs, i.e. they can have beneficial immune response (51). Previous studies have shown that $n-6$ PUFAs can affect oligodendrocytes membrane composition, and myelin formation in the rat brain can be accelerated by dietary lipids. Although the protective effects of pistachios on cellular metabolism may be due to other nutrients such as iron, potassium, and phosphorus, respectively. The data available are insufficient to assess any potential benefit or harm from PUFA supplementation (77).

\section{Pistachio and cancer}

Although the pistachio contains vitamins and micronutrients that have potential biological mechanisms of action for reducing the risk of cancer, epidemiological evidence on the effects of pistachio on the risk of cancer in humans is still limited and insufficient. In one study, pistachio in the diet following anticancer drugs such as cisplatin and vincristine had a protective effect against anticancer drug-induced disruptions in the motor and cognitive functions (78).

Recent studies showed that consumption of nuts such as pistachio reduced cancer mortality and nuts may protect individuals from prostate cancer (about 31\%) (79), colorectal and colon cancers in women, endothelial cancer (about
27\%) (80), pancreatic cancer (81), and breast cancer. However, it had a stronger effect on postmenopausal breast cancer than premenopausal breast cancer.

Pistachio consumption produced more gut microbiota composition that produced potentially beneficial butyrate-producing bacteria in comparison to almond consumption. Although the number of bifidobacteria was not affected by the consumption of the two nuts, pistachio consumption decreased the number of lactic acid bacteria. Increasing the consumption of nuts, such as pistachios, has an effect on increasing gut microbiota composition (81).

Hypotheses that explain the anticancer effects of nuts, e.g. pistachios which contain many antioxidant and anti-inflammatory substances, provide growing evidence indicating the key role of inflammation and oxidative stress in the development of specific cancer types. Since reprogramming of energy metabolism has been recently recognized as a key feature of cancer cells, nuts may affect cancer progression through their ability to alter lipid profiles and cell metabolism (82).

Prostate cancer cells appear to use acyl cholesterol acyltransferase (ACAT) to remove the excess cholesterol and store it as cholesteryl ethers in order to maintain the uptake of LDL and associated fatty acids, including the arachidonic acid that is involved in cell proliferation and growth by lowering cholesterol levels. They can reduce the accumulation of cholesteryl ethers in cancer cells, and therefore, possibly reduce the uptake of LDL and EFAs, ultimately resulting in inhibition of cancer cell proliferation and tumor growth (81). However, pistachio consumption may have anti-proliferative effects.

\section{Pistachio and inflammatory bowel disease} (IBD)

Pistachios are important sources of antioxidants that reduce inflammation and oxidative stress $(29,50)$ via inhibiting interlukin-1B that increases the expression and realization of inflammatory mediators (82). 
Antioxidants in the pistachio inhibit prostaglandin E2 and interlukin-1B-induced COX-2 protein expression that promotes colorectal tumor growth by stimulating angiogenesis, cell invasion, cell growth, and survival in humans (81).

Pistachios contain proanthocyanidins, which is a subclass of polyphenolic compounds found in plants and have anti-inflammatory activity, radical scavenging activity, and antioxidant effects (83).

On the other hand, antioxidants in pistachios increase the expression of the Antiinflammatory gene by repressing the transcription rate of interferon-induced protein with tetratricopeptide repeats (TPR) that causes inflammation in the intestine (84).

\section{Conclusions}

Studies show that nuts such as pistachio have many beneficial effects on health, and can be used for controlling different diseases.

Numerous studies have been conducted to investigate the beneficial effects of nuts such as pistachio on health and lipid profile, and diseases such diabetes, metabolic syndrome, CHD, cancer, inflammatory diseases, and MS. It is commonly believed that pistachios can be used to prevent and treat these diseases. As previously discussed in this article, pistachio has anti-inflammatory effects; therefore, consuming pistachios could be helpful in the improvement of metabolic syndrome complications.

Pistachios can delay gastric emptying time which could result in a prolonged digestion process and reduced feeling of hunger, which may manage weight well. Pistachio contains essential unsaturated fatty acids, fiber, antioxidants, and many nutrients. Thus, if taken adequately and frequently, it improves health. However, it seems that pistachio may have anti-inflammatory, anti-diabetic, antihyperlipidemic, and anti-proliferation effects.

Further studies on pistachio are suggested in order to understand whether this nut can be recommended for the prevention, improvement, or treatment of diseases such as diabetes, CVD, IBD, cancer, and MS.

\section{Acknowledgements}

The authors would like to thank the Center for Development of Clinical Research of Nemazee Hospital and Dr. Nasrin Shokrpour for her editorial assistance.

Conflict of interest: None declared.

\section{References}

1. Bozorgi M, Memariani Z, Mobli M, Salehi Surmaghi MH, Shams-Ardekani MR, Rahimi R. Five pistacia species (P. vera, P. atlantica, P. terebinthus, P. khinjuk, and P. lentiscus): a review of their traditional uses, phytochemistry, and pharmacology. ScientificWorldJournal 2013; 2013:219815. doi: 10.1155/2013/219815. eCollection 2013.

2. Zomorrodi A. Improvement of competitiveness: the case of Iranian pistachio. World Journal of Social Sciences 2014; 4(1):237-50.

3. Switzerland. World Health Organization. Noncommunicable Diseases Country Profiles. Geneve: World Health Organization; 2011 Sep. 209 p.

4. Sari I, Baltaci Y, Bagci C, Davutoglu V, Erel $\mathrm{O}$, Celik $\mathrm{H}$, et al. Effect of pistachio diet on lipid parameters, endothelial function, inflammation, and oxidative status: a prospective study. Nutrition 2010; 26(4):399404.

5. Damasceno NR, Perez-Heras A, Serra M, Cofán M, Sala-Vila A, Salas-Salvadó J, et al. Crossover study of diets enriched with virgin olive oil, walnuts or almonds. Effects on lipids and other cardiovascular risk markers. Nutr Metab Cardiovasc Dis 2011; 21(1):S14-20.

6. McKiernan F, Lokko P, Kuevi A, Sales RL, Costa NM, Bressan J, et al. Effects of peanut processing on body weight and fasting plasma lipids. Br J Nutr 2010; 104(3):418-26.

7. Colpo E, Vilanova CD, Brenner Reetz LG, Medeiros Frescura Duarte MM, Farias IL, Irineu Muller E, et al. A single consumption of high amounts of the Brazil nuts improves lipid profile of healthy volunteers. J Nutr Metab 2013; 2013:653185. doi:10.1155/2013/653185

8. Baynes JW. Role of oxidative stress in development of complications in diabetes. Diabetes 1991; 40(4):405-12.

9. Goldin A, Beckman JA, Schmidt AM, Creager MA. Advanced glycation end products: 
sparking the development of diabetic vascular injury. Circulation 2006; 114(6):597-605.

10. Franz MJ, Bantle JP, Beebe CA, Brunzell JD, Chiasson JL, Garg A, et al. Evidence-based nutrition principles and recommendations for the treatment and prevention of diabetes and related complications. Diabetes Care 2002; 25(1):148-98.

11. Krentz AJ, Ferner RE, Bailey CJ. Comparative tolerability profiles of oral antidiabetic agents. Drug Saf 1994; 11(4):223-41.

12. Shahraki J, Zareh M, Kamalinejad M, Pourahmad J. Cytoprotective effects of hydrophilic and lipophilic extracts of pistacia vera against oxidative versus carbonyl stress in rat hepatocytes. Iran J Pharm Res 2014; 13(4):1263-77.

13. Bhagwat S, Haytowitz DB, Holden JM. USDA Database for the isoflavone content of selected foods, Release 2.0. Beltsville, Maryland: Nutrient Data Laboratory, Beltsville Human Nutrition Research Center, ARS, USDA; 2008 Sep. doi: 10.15482/USDA.ADC/1209670

14. Kornsteiner M, Wagner K-H, Elmadfa I. Tocopherols and total phenolics in 10 different nut types. Food Chem 2006; 98:381-7.

15. Ballistreri G, Arena E, Fallico B. Influence of ripeness and drying process on the polyphenols and tocopherols of Pistacia vera L. Molecules 2009; 14(11):4358-69.

16. Seeram NP, Henning SM, Niu Y, Lee R, Heber D. Pistachio skin phenolics: identification, antioxidant capacities and their use as markers of bleaching. Paper presented at: The American Chemical Society Meeting \& Exposition; 2006 March 26-30; Atlanta, GA, USA.

17. Seeram NP, Zhang Y, Henning SM, Lee R, Niu Y, Lin G, et al. Pistachio skin phenolics are destroyed by bleaching resulting in reduced antioxidative capacities. J Agric Food Chem 2006; 54(19):7036-40.

18. Gentile C, Tesoriere L, Butera D, Fazzari M, Monastero M, Allegra M, et al. Antioxidant activity of Sicilian pistachio (Pistacia vera L. var. Bronte) nut extract and its bioactive components. J Agric Food Chem 2007; 55(3):643-8.

19. Bolling BW, Chen CY, McKay DL, Blumberg JB. Tree nut phytochemicals: composition, antioxidant capacity, bioactivity, impact factors. A systematic review of almonds, Brazils, cashews, hazelnuts, macadamias, pecans, pine nuts, pistachios and walnuts. Nutr Res Rev 2011; 24(2):244-75.

20. Kuhnle GG, Dell'Aquila C, Aspinall SM, Runswick SA, Mulligan AA, Bingham SA. Phytoestrogen content of beverages, nuts, seeds, and oils. J Agric Food Chem 2008; 56(16):7311-5.

21. Shike ME, Shils M. Modern nutrition in health and disease. Baltimore, Maryland, United States of America: Lippincott Williams and Wilkins; 2006. P.211-22.

22. Food and Nutrition Board (FNB), Institute of Medicine. DRI Dietary Reference Intakes: for Calcium, Phosphorus, Magnesium, Vitamin D and Fluoride. Washington (DC): The National Academies Press; 1997.

23. Davarynejad Gh, Nagy Peter T, Davarynejad E. Concentration of some major elements in the kernel of pistacia atlantica desf., p. vera variety "sarakhs", "badami zarand" and cultivated pistachio in Iran. International Journal of Nuts and Related Sciences 2012; 1(3):7-12.

24. Ross AC, Caballero B, Cousins RJ, Tucker KL, Ziegler TR. Modern nutrition in health and disease (Modern Nutrition in Health \& Disease (Shils)). 11th ed. United States of America: Lippincott Williams \& Wilkins; 2012:133-512

25. Gebauer SK, West SG, Kay CD, Alaupovic P, Bagshaw D, Kris-Etherton PM. Effects of pistachios on cardiovascular disease risk factors and potential mechanisms of action: a dose-response study. Am J Clin Nutr 2008; 88(3):651-9.

26. Banel DK, Hu FB. Effects of walnut consumption on blood lipids and other cardiovascular risk factors: a meta-analysis and systematic review. Am J Clin Nutr 2009; 90(1):56-63. doi:10.3945/ajcn.2009.27457.

27. Alturfan AA, Emekli-Alturfan E, Uslu E. Consumption of pistachio nuts beneficially affected blood lipids and total antioxidant activity in rats fed a high-cholesterol diet. Folia Biol (Praha) 2008; 55(4):132-6.

28. Edwards K, Kwaw I, Matud J, Kurtz I. Effect of pistachio nuts on serum lipid levels in patients with moderate hypercholesterolemia. J Am Coll Nutr 1999; 18(3):229-32.

29. Kocyigit A, Koylu AA, Keles H. Effects of pistachio nuts consumption on plasma lipid profile and oxidative status in healthy volunteers. Nutr Metab Cardiovasc Dis 2006; 16(3):202-9.

30. Sheridan MJ, Cooper JN, Erario M, Cheifetz CE. Pistachio nut consumption and serum lipid levels. J Am Coll Nutr 2007; 26(2):141-8.

31. Abate N, Chandalia M, Snell PG, Grundy SM. Adipose tissue metabolites and insulin resistance in nondiabetic Asian Indian men. J Clin Endocrinol Metab 2004; 89(6):2750-5.

32. Misra A, Sharma R, Gulati S, Joshi SR, Sharma V, Ghafoorunissa, et al. Consensus dietary guidelines for healthy living and 
prevention of obesity, the metabolic syndrome, diabetes, and related disorders in Asian Indians. Diabetes Technol Ther 2011; 13(6):683-94.

33. Bes-Rastrollo M, Sabate J, Gomez-Gracia E, Alonso A, Martínez JA, Martínez-González MA. Nut consumption and weight gain in a Mediterranean cohort: The SUN study. Obesity (Silver Spring) 2007; 15(1):107-16.

34. Casas-Agustench P, Bullo M, Ros E, Basora J, Salas-Salvadó J; Nureta-PREDIMED investigators. Cross-sectional association of nut intake with adiposity in a Mediterranean population. Nutr Metab Cardiovasc Dis 2011; 21(7):518-25.

35. Misra A. Impact of ethnicity on body fat patterning in Asian Indians and blacks: relation with insulin resistance. Nutrition 2003; 19(9):815-6.

36. Gentile C, Tesoriere L, Butera D, Fazzari M, Monastero M, Allegra M, et al. Antioxidant activity of sicilian pistachio (Pistacia vera $\mathrm{L}$. var. Bronte) nut extract and its bioactive components. J Agric Food Chem 2007; 55(3):643-8.

37. Baer DJ, Gebauer SK, Novotny JA. Measured energy value of pistachios in the human diet. Br J Nutr 2011; 107(1):120-5.

38. Parham M, Heidari S, Khorramirad A, Hozoori M, Hosseinzadeh F, Bakhtyari L, et al. Effects of pistachio nut supplementation on blood glucose in patients with type 2 diabetes: a randomized crossover trial. Rev Diabet Stud 2014; 11(2):190-6.

39. Li Z, Song R, Nguyen C, Zerlin A, Karp H, Naowamondhol K, et al. Pistachio nuts reduce triglycerides and body weight by comparison to refined carbohydrate snack in obese subjects on a 12-week weight loss program. J Am Coll Nutr 2010: 29(3):198-203.

40. Kay CD, Gebauer SK, West SG, Kris-Etherton PM. Pistachios increase serum antioxidants and lower serum oxidized-LDL in hypercholesterolemic adults. J Nutr 2010; 140(6):1093-8.

41. Kennedy-Hagan K, Painter JE, Honselman C, Halvorson A, Rhodes K, Skwir K.. The effect of pistachio shells as a visual cue in reducing caloric consumption. Appetite 2011; 57(2):418-20.

42. Edwards K, Kwaw I, Matud J, Kurtz I. Effect of pistachio nuts on serum lipid levels in patients with moderate hypercholesterolemia. J Am Coll Nutr 1999; 18(3):229-32.

43. Wang X, Li Z, Liu Y, Lv X, Yang W. Effects of pistachios on body weight in Chinese subjects with metabolic syndrome. Nutr J 2012; 11:20.
44. Zhai F, Wang H, Wang Z, Popkin BM, Chen C. Closing the energy gap to prevent weight gain in China. Obes Rev 2008; 9(Suppl 1):10712.

45. Hoang KC, Le TV, Wong ND. The metabolic syndrome in East Asians. J Cardiometab Syndr 2007; 2(4):276-82.

46. Zheng Y, Stein R, Kwan T, Yu C, Kwan J, Chen SL, et al. Evolving cardiovascular disease prevalence, mortality, risk factors, and the metabolic syndrome in China. Clin Cardiol 2009; 32(9):491-7.

47. Marchesini G, Avagnina S, Barantani EG, Ciccarone AM, Corica F, Dall'Aglio E, et al. Aminotransferase and gammaglutamyltranspeptidase levels in obesity are associated with insulin resistance and the metabolic syndrome. J Endocrinol Invest 2005; 28(4):333-9.

48. Zhang Y, Lu X, Hong J, Chao M, Gu W, Wang $\mathrm{W}$, et al. Positive correlations of liver enzymes with metabolic syndrome including insulin resistance in newly diagnosed type 2 diabetes mellitus. Endocrine 2010; 38(2):181-7.

49. Gebauer SK, West SG, Kay CD, Alaupovic P, Bagshaw D, Kris-Etherton PM. Effects of pistachios on cardiovascular disease risk factors and potential mechanisms of action: a dose-response study. Am J Clin Nutr 2008; 88(3):651-9.

50. London HA, Pawlak R, Colby SE, WallBassett E, Sira N. The Impact of Pistachio Consumption on Blood Lipid Profile. Am J Lifestyle Med 2013; 7(4):274-7.

51. Josse AR, Kendall CW, Augustin LS, Ellis PR, Jenkins DJ. Almonds and postprandial glycemia-a dose-response study. Metabolism 2007; 56(3):400-4.

52. Holligan SD, West SG, Gebauer SK, Kay CD, Kris-Etherton PM. A moderate-fat diet containing pistachios improves emerging markers of cardiometabolic syndrome in healthy adults with elevated LDL levels. Br J Nutr 2014; 112(5):744-52.

53. United States of America, National Institues of Health.The Practical Guide Identification, Evaluation and Treatment of Overweight and Obesity in Adults. Alexandria, Virginia: National Institues of Health Publication, 2000 Oct. Report No.:00-4084.

54. US Department of Agriculture. Dietary guidelines for Americans for a healthier life. United States of America: Nutrition Evidence Library; 2010.

55. Mukuddem-Petersen J, Oosthuizen W, Jerling JC. A systematic review of the effects of nuts on blood lipid profiles in humans. J Nutr 2005; 135(9):2082-9. 
56. Nash SD, Nash DT. Nuts as part of a healthy cardiovascular diet. Curr Atheroscler Rep 2008; 10(6):529-35.

57. Nash SD, Westpfal M. Cardiovascular benefits of nuts. Am J Cardiol 2005; 95(8):963-5.

58. Nus M, Ruperto M, Sanchez-Muniz FJ. [Nuts, cardio and cerebrovascular risks. A Spanish perspective]. Arch Latinoam Nutr 2004; 54(2):137-48.

59. G Askari, N Yazdekhasti, N Mohammadifard, Sarrafzadegan N, Bahonar A, Badiei M, et al. The relationship between nut consumption and lipid profile among the Iranian adult population; Isfahan Healthy Heart Program. Eur J Clin Nutr 2013; 67:385-9.

60. Damasceno NR, Perez-Heras A, Serra M, Cofán M, Sala-Vila A, Salas-Salvadó J, et al. Crossover study of diets enriched with virgin olive oil, walnuts or almonds. Effects on lipids and other cardiovascular risk markers. Nutr Metab Cardiovasc Dis 2011; 21(Suppl 1):S1420.

61. West SG, Gebauer SK, Kay CD, Bagshaw DM, Savastano DM, Diefenbach C, et al. Diets containing pistachios reduce systolic blood pressure and peripheral vascular responses to stress in adults with dyslipidemia. Hypertension 2012; 60(1):58-63.

62. Fischer S, Glei M. Potential health benefits of nuts. Ernaehrungs Umschau international 2013; 60(12):206-15.

63. Kendall CW, West SG, Augustin LS, Esfahani A, Vidgen E, Bashyam B, et al. Acute effects of pistachio consumption on glucose and insulin, satiety hormones and endothelial function in the metabolic syndrome. Eur J Clin Nutr 2014; 68(3):370-5.

64. Kasliwal RR, Bansal M, Mehrotra R, Yeptho KP, Trehan N. Effect of pistachio nut consumption on endothelial function and arterial stiffness. Nutrition 2015; 31(5):678-85. doi.org/10.1016/j.nut.2014.10.019

65. Sauder KA, McCrea CE, Ulbrecht JS, KrisEtherton PM, West SG. Pistachio nut consumption modifies systemic hemodynamics, increases heart rate variability, and reduces ambulatory blood pressure in wellcontrolled type 2 diabetes: a randomized trial. J Am Heart Assoc 2014; 3(4). pii: e000873. doi: 10.1161/JAHA.114.000873.

66. Kashaninejad M, Mortazavi A, Safekordi A, Tabil LG. Some physical properties of Pistachio (Pistacia vera L.) nut and its kernel. J Food Eng 2006; 72(1):30-8.

67. Toshima S, Hasegawa A, Kurabayashi M, Itabe $\mathrm{H}$, Takano T, Sugano J, et al. Circulating oxidized low density lipoprotein levels. A biochemical risk marker for coronary heart disease. Arterioscler Thromb Vasc Biol 2000; 20(10):2243-7.

68. Kaplan M, Aviram M. Oxidized low density lipoprotein: atherogenic and proinflammatory characteristics during macrophage foam cell formation. An inhibitory role for nutritional antioxidants and serum paraoxonase. Clin Chem Lab Med 1999; 37(8):777-87.

69. Hernández-Alonso P, Salas-Salvadó J, Baldrich-Mora M, Juanola-Falgarona M, Bulló M. Beneficial effect of pistachio consumption on glucose metabolism, insulin resistance, inflammation, and related metabolic risk markers: a randomized clinical trial. Diabetes Care 2014; 37(11):3098-105.

70. Payne A. Nutrition and diet in the clinical management of multiple sclerosis. J Hum Nutr Diet 2001; 14(5):349-57.

71. Mauriz E, Laliena A, Valleio D, Tuñón MJ, Rodríguez-López JM, Rodríguez-Pérez R. Effects of a low-fat diet with antioxidant supplementation on biochemical markers of multiple sclerosis long-term care residents. Nutr Hosp 2013; 28(6):2229-35. doi:10.3305/nutr hosp.v28in06.6983.

72. Munger K, Ascherio A. Prevention and treatment of MS: studying the effects of vitamin D. Mult Scler J 2011; 17(12):1405-11.

73. Farinotti M, Vacchi L, Simi S, Di Pietrantonj C, Brait L, Filippini G. Dietary interventions for multiple sclerosis. Cochrane Database Syst Rev 2012; 12:CD004192. doi:10.1002/14651858.CD004192.pub3.

74. González CA, Salas-Salvadó J. The potential of nuts in the prevention of cancer. Br J Nutr 2006; 96(Suppl 2):S87-94.

75. Jain MG, Hislop GT, Howe GR, Ghadirian P. Plant foods, antioxidants, and prostate cancer risk: findings from case-control studies in Canada. Nutr Cancer 1999; 34(2):173-84.

76. Petridou E, Kedikoglou S, Koukoulomatis P, Dessypris N, Trichopoulos D. Diet in relation to endometrial cancer risk: a case-control study in Greece. Nutr Cancer 2002; 44(1):16-22.

77. Bao Y, Hu FB, Giovannucci EL, Wolpin BM, Stampfer MJ, Willett WC, et al. Nut consumption and risk of pancreatic cancer in women. Br J Cancer 2013; 109(11):2911-6.

78. Ukhanova M, Wang X, Baer DJ, Novotny JA, Fredborg M, Mai V. Effects of almond and pistachio consumption on gut microbiota composition in a randomised cross-over human feeding study. Br J Nutr 2014; 111(12):214652.

79. Falasca M, Casari I, Maffucci T. Cancer chemoprevention with nuts. J Natl Cancer Inst 2014; 106(9). pii: dju238. doi: 10.1093/jnci/dju238. 
80. McGhie TK, Rowan DD .Metabolomics for measuring phytochemicals, and assessing human and animal responses to phytochemicals, in food science. Mol Nutr Food Res 2012; 56(1):147-58.

81. Wang D, Dubois RN. The role of COX-2 in intestinal inflammation and colorectal cancer. Oncogene 2010; 29(6):781-8. doi:10.1038/onc.2009.421

82. Hernández-Alonso $P$, Salas-Salvadó J, Baldrich-Mora M, Mallol R, Correig X, Bulló $\mathrm{M}$. Effect of pistachio consumption on plasma lipoprotein subclasses in pre-diabetic subjects. Nutr Metab Cardiovasc Dis 2015; 25(4):396402.

83. Gentile C, Angileri F, Pintaudi AM, Attanzio A, Allegra M, Tesoriere L, et al. Antiinflammatory effects of pistachio nut proanthocyanidins in LPS-stimulated RAW264.7 cells. Paper Presented at: The ALIMED 2011- Mediterranean Diet quality, safety and health. 2011 May 22-25; Palermo, Italy.

84. Zhang J, Thompson JT, Vanden Heuvel JP, Kris-Etherton PM. Using nutrigenomic techniques to determine anti-inflammatory effects of pistachio oil in mouse macrophage cells. The FASEB Journal 2007; 21:A1102.

85. Saitta M, Giuffrida D, La Torre GL, Potortì AG, Dugo G. Characterisation of alkylphenols in pistachio (Pistacia vera L.) kernels. Food Chem 2009; 117(3):451-5.

86. Gulati S, Misra A, Pandey RM, Bhatt SP, Saluja S. Effects of pistachio nuts on body composition, metabolic, inflammatory and oxidative stress parameters in Asian Indians with metabolic syndrome: a 24-wk, randomized control trial. Nutrition 2014; 30(2):192-7.
87. Nieman DC, Scherr J, Luo B, Meaney MP, Dréau D, Sha W, et al. Influence of pistachios on performance and exercise-induced inflammation, oxidative stress, immune dysfunction, and metabolite shifts in cyclists: a randomized, crossover trial. PLoS One 2014; 9(11):e113725.

doi: 10.1371/journal.pone.0113725. eCollection 2014.

88. Gentile C, Perrone A, Attanzio A, Tesoriere L, Livrea MA. Sicilian pistachio (Pistacia vera L.) nut inhibits expression and release of inflammatory mediators and reverts the increase of paracellular permeability in IL-1 $\beta$ exposed human intestinal epithelial cells . Eur J Nutr 2015; 54(5):811-21.

89. Bagheri M, Maghsoudi Z, Fayazi S, Elahi N, Tabesh H, Majdinasab N. Several food items and multiple sclerosis: A case-control study in Ahvaz (Iran). Iran J Nurs Midwifery Res 2014; 19(6):659-65.

90. Farzanegi P, Mousavi M, Ghanbari-Niaki A. Effect of pistacia atlantica extract on glutathione peroxidase tissue levels and total oxidative capacity of liver and plasma lipid profile of rats. Zahedan Journal of Research in Medical Sciences 2013; 15(11):59-63.

91. Mandalari G, Bisignano C, Filocamo A, Chessa S, Sarò $M$, Torre $G$, et al. Bioaccessibility of pistachio polyphenols, xanthophylls, and tocopherols during simulated human digestion. Nutrition 2013; 29(1):33844.

92. Aksoy N, Aksoy M, Bagci C, Gergerlioglu HS, Celik H, Herken E, et al. Pistachio intake increases high density lipoprotein levels and inhibits low-density lipoprotein oxidation in rats. Tohoku J Exp Med 2007; 212(1):43-8. 